\title{
SOME PROBLEMS OF DEFENSE
}

\section{By Amos S. Hershey,}

Professor of Political Science and International Law, Indiana University.

In this crisis of the nation's history, I have thought that some consideration of problems or methods of defense would not be out of place. Knowing little of military matters, I shall leave it to military experts to decide upon the means and methods of military defense. I wish merely to pose some general problems and discuss means and methods from a diplomatic rather than a military standpoint.

First let us consider the main objects, or perhaps we had better say, subjects of defense. These may be said to consist of the nation's frontier, the strategic points commanding the entrances to the Gulf of Mexico and the Panama Canal, and other vital interests, such as the Monroe Doctrine and the freedom of the seas, more particularly of the great trade routes on the Atlantic, Pacific, and the Mediterranean.

With respect to the nation's territory, it may be observed that, if we except the possibility of war with Canada or England, it includes only one exposed frontier-that of the Philippine Islands. It is useless now to indulge in vain regrets over our great mistake in taking over this hostage to fortune, but a frank recognition of our blunder may help us in the solution of the difficult problem of making a wise disposition of these Islands and in avoiding similar pitfalls in the future.

It will, I think, be generally agreed that our northern and southern frontiers are relatively safe from attack or invasion. I think the same can be said of our eastern and western coasts. I believe the invention and improvement of the submarine will practically insure us against invasion on either the Atlantic or Pacific seaboards. It is inconceivable that a fleet of transports even if covered by the great guns of modern calibre on board dreadnoughts and battleships should be able to effect a landing of troops in the face of a goodly number of up-to-date submarines. Whether these sea wasps will be able to prevent the bombardment of our coast towns and the infliction of serious damage remains to be seen. 
Sharing with Great Britain, as we do, important strategic points in the Bahamas and the West Indies, the Caribbean entrance to the Panama Canal is practically at the mercy of England. We are likewise largely dependent upon the mistress of the seas for the maintenance and enforcement of the Monroe Doctrine.

I do not propose to enter upon a discussion of the merits or demerits of this doctrine. Whether it be a wise or a foolish doctrine is not pertinent to this discussion. It may be a "shibboleth" but it is certainly not an "obsolete shibboleth," as one critic has termed it. This he would soon discover, if he undertook to violate it at the head of an army or a navy. Upon no point are the American people more sensitive or determined than upon the maintenance of this doctrine. This was illustrated by the instantaneous and vociferous approval of President Cleveland's application of the doctrine to the boundary dispute between England and Venezuela in 1895. It is shown today by the suspicious attitude of the American press and of the American people toward alleged Japanese activities in Mexico.

Originally suggested by Great Britain for selfish reasons of her own, though at times flouted and disregarded by her, the Monroe Doctrine, at least in its essence, has become almost as much a British as an American interest. Certainly we are largely dependent upon the good will of England for its maintenance unless we choose to enter upon a long and exhausting career of naval rivalry with her and attempt to build a navy equal or superior to her own. For the enforcement of the Monroe Doctrine is primarily a matter of sea power.

The Monroe Doctrine is often said to be vague, ill-defined, and uncertain in its meaning and application. This may be true with reference to certain implications or corollaries which have been drawn from the doctrine, such as the degree or extent of our responsibilities for the preservation of order or the payment of obligations contracted or guaranteed by Latin American states. But it is not true with reference to the essence or substance of the doctrine itself, upon which nearly all authorities seem to be agreed. The consensus of opinion is that the American people or government would not tolerate without resistance the permanent occupation, a future attempt at colonization, or an endeavor to control the political destiny of any portion of this hemisphere by any European power. 
A nother vital interest of America is the freedom of the sea, the common highway of nations, more particularly the great trade routes on the Atlantic, Pacific, and the Mediterranean.

For a century or more we have acquiesced in British naval supremacy partly, I suppose, because it was regarded as a settled and inevitable fact, but mainly because it has been to our advantage to do so. In the navies this trust of sea power has been administered in a liberal, considerate, and non-despotic manner.

True it is that Great Britain has managed to occupy many of the best strategic points and most important colonies on the great trade routes, but she has maintained an open door so far as possible and has granted equal opportunities of trade to all nations, not even excluding her recent arch enemy, Germany, who has grown fat and prospered under the free trade policy of England the same as we have.

Even during the present struggle, though we are not permitted to trade with Germany which is in a state of virtual siege or blockade, our trade flourishes under the protection of the British flag. Great Britain has managed to keep the great trade routes of the Atlantic open in spite of a method of warfare new and unprecedented in the history of civilization.

Imagine the effect upon our commerce of a successful or effective blockade of the British Isles or of the destruction of the British fleet, whether by legal or illegal and inhumane methods of warfare! Commercial ruin, a financial panic, bankruptcy on a scale hitherto unknown would inevitably follow in the wake of such a calamity. How could the sale and delivery of cotton, copper, arms and ammunition, or even of foodstuffs to Germany compensate us for such frightful losses?

And what of the future? What expectations or prospects of a wise, liberal, and benevolent régime would there be in a future with the trident in the hands of Germania? The answer may be found in the traditions, history, and spirit of Prussian militarism and in a bare enumeration of some of the numerous acts of German brutality which have defaced the pages of modern history-such acts as the treacherous invasion of Silesia by Frederick the Great in 1740, the treatment within recent years of Alsace Lorraine and Prussian Poland, the piratical seizure of Kiao-chow for the murder of two German priests in 1898, the excesses of the German troops in China dur- 
ing the Boxer uprising in 1900 directly inspired by the Kaiser, the rape of Belgium, the destruction of Louvain and of many other wellattested German atrocities in Belgium and France, the countless violations of the letter and spirit of international law during the Franco-Prussian as well as the present war, and finally the destruction of the Lusitania.

Another vital interest (which is also a matter of national honor) is the protection of our own citizens on the high seas or in foreign lands-a duty too much neglected by our government during late years. It is possible to be too aggressive and sensitive in this matter, but a nation which fails in this important duty will soon find itself losing in self-respect and lowered in the esteem of the world.

Now what are the chief means and methods of defense? In such a world as this the first and main reliance of a nation must always be upon its own strength. We must depend chiefly upon our navy, the discussion of details bearing upon whose increase and improvement, I leave to naval experts.

It is, I believe, generally agreed that, in addition to an increased and improved personnel, the greatest present-day needs of our navy are perhaps several hundred submarines, a considerable number of swift battle cruisers, together with a variety of air and sea craft such as aeroplanes, hydroplanes, torpedo-boat destroyers, etc.

There is an additional method of defense which is generally employed by other nations than the United States. It is that of leagues or alliances.

We have relied mainly upon our geographical isolation for immunity from attack. It is not many years since England was forced to abandon her policy of "splendid isolation," and it is probably only a question of time when we shall come to see that our traditional policy of freedom from entangling alliance may need modification. At any rate it would be well to consider the question with minds unhampered by prejudice.

I do not for a moment question the wisdom of the Fathers in committing us to a policy of non-entangling alliances during the formative period in the history of our Republic, nor do I question the wisdom of their successors in following the policy until recent times. But we live in a changed and rapidly changing world of international relations. The United States is now a world power 
and cannot indefinitely continue to evade the duties and responsibilities incumbent upon her as a world power.

Besides, the modern means and methods of intercommunication between nations (largely the result of the application of steam, oil, water-power, and electricity, together with the invention of the telegraph, telephone, and the various forms of aircraft) will soon make it evident to nearly all of us that a policy based on the idea of geographical isolation and separate national interests and ideals cannot always be successfully maintained. In spite of appearances to the contrary offered by the fearful spectacle of the great European war, the nations are rapidly becoming more and more intimately bound one to another in a spiritual as well as a material sense; and the illusions of nationality, state sovereignty, and independence are rapidly giving way to the great facts of international solidarity and interdependence. Even the present war is a demonstration of the superior power of ideals based upon the ideas of freedom, humanity, coöperation, and democracy over those based upon mere nationalism, bureaucratic autocracy, militarism, and brute force.

Occupying, as we do, a position in the great ocean between Great Britain and France on the Atlantic and Japan and Russia on the Pacific, all now bound in close alliance, would it not be well to look ahead and cultivate closer relations with these powers, particularly with England and France? Until Germany is either crushed or converted to the ideals of peaceful intercourse, democracy and humanity, there can be no permanent peace between her and the Allies. We may sooner or later be forced to take a position on one side or the other of this conflict as was the case during the Napoleonic struggles. Heaven grant it may not be on the side directly opposed to our national interests and the cause of humanity as then happened. We could not afford to repeat that error.

A recent facile and somewhat reckless writer has predicted that we shall be compelled, sooner or later, to fight the victor in this war, whether it be England or Germany. I have long been of the opinion that Germany was a menace not only to Europe, but to America and the Far East as well. If Napoleon had effected a permanent conquest of Europe, his "manifest destiny" would have called him to America and India. In 1803 he was forced to choose 
between America and Europe. He chose Europe. Hence the sale of Louisiana to the United States.

A war with England is inconceivable. It is in the highest degree improbable because we have behind us a century of peaceful intercourse. Then, too, our language and literature, our institutions, our customs, our religion even are for the most part of Anglo-Saxon origin. In spite of past differences, of real and imaginary grievances, in spite of much mutual dislike and a number of family quarrels, the two peoples are united not merely by genuine bonds of sentiment but by the indissoluble ties of sympathy and interest. A blow at the heart of Great Britain would inflict serious, if not fatal, injury upon the United States.

The existing interdependence between Great Britain and the United States stands revealed more clearly than ever in this war. The destruction of the British fleet or of British commerce by German submarines would be only less disastrous to the United States than to Great Britain. The destruction of the Lusitania has brought it home to us that just as Great Britain and France are largely dependent upon us for food and other supplies, so are we largely dependent upon British sea-power not merely for a continuance of our prosperity but for our very security and peace of mind.

What is the solution for this precarious situation? Is it that we must enter into naval rivalry with Great Britain? Is it not rather that, while augmenting and improving our means of defense, particularly the navy, we must draw still closer the bonds which unite us to the British Empire and to France? Whether we realize it or not, whether we like it or not, we are already a powerful, albeit silent member of that great free Confederacy of English speaking peoples which compose the most important part of the British Empire.

An additional reason for joining or openly proclaiming our allegiance to this league of free peoples which, with the addition of France and possibly of Italy and Japan, might readily be transformed into the League of Peace, advocated by many distinguished peace advocates, may be found in conditions in the Far East.

The recent treatment of China by Japan furnishes a sad commentary upon the aims and methods of Japanese policy which now stands revealed to all the world. Japan has shown her hands, but whether she will play her cards depends upon future events. It will probably be found at the end of this war that she has acted in con- 
cert with Russia and it will lie largely with England and the United States whether or not she is to be thwarted in her designs upon China. It is not likely that Japan desires the Philippine Islands, but they form a very vulnerable point of attack and if we decide to retain or protect this exposed frontier at all hazards, we may eventually have to choose between a Far Eastern fleet equal or superior to that of Japan or an alliance with Great Britain. 